\title{
The Effect of Using E-Learning Based Guided Discovery Learning Model Based on Self-Efficacy Towards Student Learning Outcomes In Biology Class in Reproductive System Subject in High School
}

\author{
Umu Atiyah ${ }^{1, a *}$, Mieke Miarsyah $^{1, b}$, \& Diana Vivanti Sigit ${ }^{1, c}$ \\ ${ }^{1}$ Department of Biology Education, State University of Jakarta, Jakarta, 13220, Indonesia \\ a*umusmancar@gmail.com; b miekemiarsyah@yahoo.com; c dianavivanti@yahoo.com \\ *Corresponding Author : umusmancar@gmail.com | Phone : +62817759714
}

\begin{abstract}
Guided Discovery Learning is a learning model that is considered capable of improving student learning outcomes while Self-efficacy is self-confidence in an individual's abilities. This study aims to determine the effect of guided discovery learning model and self-efficacy towards student learning outcomes in biology class. The method used in this research is quasi-experimental. This study has a sample of 200 students from 256 students. The technique used is Cluster random sampling. The instruments used are multiple choices and questionnaire. Data from the three variables are analysed using the Two-Way ANOVA Test and the Tukey Test, at a significance level of 0.005 . Based on data analysis, it can be concluded that Guided Discovery Learning model and an individual's self-efficacy can improve student learning outcomes. Both Guided Discovery Learning model and self-efficacy can improve student learning outcomes and have positive interactions between the two variables. The implications of this study are as a basis for increasing the use of learning models using technology, and teachers as educators are able to encourage students to improve self-efficacy.
\end{abstract}

Keywords: Guided Discovery Learning; Self-Efficacy; Learning Outcomes; Biology Class;

\section{Introduction}

Learning is a process of behaviour change that occurs in individuals caused by an interaction of individuals with other individuals or with their environment. According to Slameto (2010), learning is behaviour change that occurs in individuals due to the process of experience or interaction with the environment. Hamalik (2008) added that learning is a process to achieve a change and not only a result. The implementation of Undang-Undang Nomor 20 Tahun 2003 concerning the National Education System is elaborated into a number of regulations. In order to manifest purpose of the system, Graduation Competency Standards have been established which are criteria regarding the qualifications of graduates' abilities that include knowledge, attitudes and skills. Based on PISA data in 2015, Indonesia showed a very significant increase in education achievement by 22.1 points. Increasing Indonesia's achievements in 2015 is sufficient to provide national optimism, but there is still a lot of effort needed to continue improving the quality of education because its achievements are still below the Organization for Economic Cooperative and Deflation / OECD (Kemendikbud, 2016). Based on PISA, it shows that literacy reading, mathematics literacy, scientific literacy achieved by students in Indonesia is still very low (Kemendikbud, 2017). It proves that student learning outcomes are still below average. Based on the results of the UN (Ujian Nasional) or National Exam at the SMA and MA in 2018, there are several problems that occur in the implementation of the UN, one of the problems that occurs in the implementation of the UN is the difficulty of the questions given. The Minister of Education and Culture, Muhadjir Effendy, states that the Mathematics and Natural Sciences problems had different assessments, namely using international standards in the format of the assessment which required higher-order thinking skills as learning outcomes (Kemendikbud, 2018).

The results of direct observations show that there are still students who are in below average learning outcomes, especially on the subject of the reproductive system. The subject of the reproductive system is very important. Because the subject is about genital, students' ability in thinking and analysing the problem of negative impacts are also still low. The mindset and understanding the concept of the reproductive 
system is still considered taboo. They feel more ashamed. According to Sridailani, et al (2018), it is states that understanding the concept of student reproduction system has not reached high capacity, from 32 students only $6.25 \%$ included in the high category. Self-confidence in maintaining about genital and problem solving tends to seem shut, while the great expectations of learning outcomes, students are able to improve high analysis and encourage students to have an open-mind. Other than that, students are also required to be able to share information from one concept to another and be able to process information and its implementations. It is known that the government demands the process of learning outcomes are students being able to coordinate between skills and the ability to think critically and creatively in order to manifest imaginative innovation ideas. (Chinedu et all, 2015).

The goal of minimizing these problems requires a learning strategy and innovation. One learning model that is considered capable of increasing the ability to think highly is Guided Discovery Learning. According to Golaiman (2013), Guided Discovery Learning is a learning model that encourages students to interact with the environment in order to understand an object. This model also requires students to find knowledge more actively and to build their own knowledge. When students are trained to be able to build and find their own knowledge, students will try to relate the information they get, use the information they get to solve problems, and analyze the information so students are able to find their own knowledge. Training students in managing information to solve problems is expected to improve students' higher-order thinking skills. An optimization and an implementation of the Guided Discovery Learning model are required in the class and the learning media is needed so that students will be more helped in understanding the subject. One of the medias that can help the learning process in class is e-learning media. E-learning media can assist students in finding information in order to find their own knowledge, e-learning can also help students to more easily understand an abstract material to become real.

One type of e-learning that can help students in finding their own knowledge with a variety of information that is easily obtained is online-based e-learning media (Moore, 2011), Budi Oetomo (2002) added that the internet can be used as an electronic media-based learning media. Online e-learning media will help students to more easily obtain various kinds of information that can assist students in practicing students' high-level thinking skills by analysing and linking various kinds of information that they get so students can build their own knowledge. The use of Guided Discovery Learning model with online-based elearning media is expected to be able to improve students' high-level thinking skills and be able to improve students' learning outcomes in Biology. Efforts to improve learning outcomes are external and internal factors. One internal factor that can help increasing student learning outcomes is self-efficacy. Self-efficacy is a person's sense of confidence in the ability and tenacity in completing work. Self-efficacy has a very important role in the success of a person to complete a job or task. Bandura (1986) states that self-efficacy is the ability and tenacity of a person in managing their abilities to achieve the expected goals. Zulkosky (2009) adds that self-efficacy is related to the assumption that a person is able to complete every job. Students with high self-efficacy will be able to regulate every action what they have to do to get high learning outcomes. So that self-efficacy becomes a very important part in determining the success of student learning in school. Based on the description above, the author intends to conduct a study "The Effect of Using E-Learning Based Guided Discovery Learning Model Based on Self-Efficacy on Results of Student in Biology Class in Reproductive System Subject."

\section{Methods}

The method used in this study is a quasi-experiment with $2 \times 2$ research design. The following table will show the more information:

Tabel 1. Research Design $2 \times 2$

\begin{tabular}{cccc}
\hline & & \multicolumn{2}{c}{ Guided Discovery Learning } \\
\cline { 2 - 4 } Self-efficacy & e-learning (A1) & Textbooks (A2) \\
High (B1) & A1B1 & A2B1 & \\
Low (B2) & A1B2 & A2B2 & \\
\hline
\end{tabular}

Note:

A1B1 : Learning outcomes in Biology class by students in group using E-Learning based Guided Discovery Learning model with high Self-Efficacy

A1B2 : Learning outcomes in Biology class by students in group using E-Learning based Guided Discovery Learning model with low Self-Efficacy.

A2B1 : Learning outcomes in Biology class by students in group using Textbooks based Guided Discovery Learning model with high Self-Efficacy.

A2B2 : Learning outcomes in Biology class by students in group using Textbooks based Guided Discovery 
Learning model with low Self-Efficacy.

A1 : A group of students using E-Learning based Guided Discovery Learning model.

A2 : A group of students using Textbooks based Guided Discovery Learning model.

B1 : A group of students with high Self-Efficacy.

B2 : A group of students with low Self-Efficacy.

\section{Population and Sample}

The population in this study were all students in SMAN in Serang City. Determination of the sample is done by using multistage sampling technique. The first level of sample is selected by purposive sampling, which is to choose high school in Serang. At the second level of all the schools, SMA Negeri 2 Serang City was selected, using random cluster sampling. At the third level, students from grade XI IPA 1 to XI IPA 8 were sampled by random sampling using the Mc. Clave formula and 200 samples were obtained of 256 students. The number of samples of students who have both high and low Self-Efficacy is taken 27 percent of the 100 samples in the experimental and control groups, so that each sample is obtained 27.

\section{Condition Data Collection Technique}

The data collection in this study uses the instrument of learning outcomes in the form of biology questions for student learning outcomes variable (y) and the instrument of Self-Efficacy in statements form variable $(X)$. Biology questions and statements forms were tested before being used as instruments. The testing of biology questions and statements forms include validity and reliability testing. This test produces valid dan invalid biology questions and statements forms. Invalid biology questions and statements forms are discarded or cannot be used in further research.

\section{Results And Discussions}

Table 2. Two-way ANOVA Testing

\begin{tabular}{|c|c|c|c|c|c|c|}
\hline No & Variable & Total & Mean & $\mathrm{F}$ & Sig & $\mathrm{df}$ \\
\hline 1 & Corrected Model & $7437,421^{a}$ & 2479,14 & 20,555 & 000 & 3 \\
\hline 2 & Intercept & 225461 & 225461 & 1869,353 & ,000 & 1 \\
\hline 3 & Learning Model(A) & 3638,11 & 3638,11 & 30,164 & ,000 & 1 \\
\hline 4 & Self-efficacy (B) & 3041,887 & 3041,887 & 25,221 & ,000 & 1 \\
\hline 5 & Model GDL *Self-efficacy $\left(A^{*} B\right)$ & 757,423 & 757,423 & 6,280 & ,014 & 1 \\
\hline 6 & Error & 12543,34 & 120,609 & & & 104 \\
\hline 7 & Total & 245441,7 & & & & 108 \\
\hline 8 & Corrected Total & 19980,77 & & & & 107 \\
\hline
\end{tabular}

The two-way ANOVA test results show between students with e-learning based GDL model and textbooks obtained sig. $p=0,000$. Significance results $p<0.05$ which means that there is an effect of learning models based on e-learning and GDL based on textbooks on student learning outcomes. This effect can be seen from the average value of Biology student learning outcomes on the implementation of the GDL learning model. ANOVA two-way test results between students who have high self-efficacy with students who have low self-efficacy obtained significance $p=0,000$. Significance results $p<0.05$ which means that there is an effect of Self-Efficacy on student' learning outcomes in Biology class. This effect can be seen from the average value of learning outcomes in Biology class of students whose self-efficacy is higher than the average value of learning outcomes in Biology class of students whose self-efficacy is low both in classes that use e-learning based GDL or textbooks.

The two-way ANOVA test between the GDL model and self-efficacy obtained a value of 0.014 . Significance results shows $\mathrm{p}<0.05$ which means there is an effect of interaction between Guided Discovery Learning, self-efficacy on learning outcomes in Biology class. This effect can be seen in the average value of learning outcomes in Biology class of A1B1 students at 59.45, A2B1 groups at 42.55, meaning A1B1 > A2B1 and A1B2 at 43.54, A2B2 group at 37.23, meaning A1B2 > A2B2 (A1 > A2) and also A1B1 > A1B2 and A2B1> A2B2 (B1 > B2). The two-way ANOVA test results show the interaction between the GDL model and Selfefficacy with a significance of $\mathrm{P}=014$, meaning $<0.05$, which means there is an effect of interaction between Guided Discovery Learning and self-efficacy on student learning outcomes in Biology class, therefore it is continued with the Tukey test. Tukey's testing procedure is to compare one comparison with another sample group at the same amount, if the significance of the test $<0.05$, it can be concluded that there is a significant effect between the sample groups. The results of the Tukey test can be seen in the table 3 . 
Table 3. Conclusion of the Significance Value

\begin{tabular}{ccc}
\hline Groups & Significance Value & Conclusion \\
\hline A1B1 & $<0,05$ & There is a significant effect among A1B1 with A1B2, A2B1 and A2B2 \\
A1B2 & $>0,05$ & There is no significant effect among A1B2 with A2B1 and A2B2 \\
A2B1 & $>0,05$ & There is no significant effect among A2B1 with A1B2 and A2B2 \\
A2B2 & $>0,05$ & There is no significant effect among A2B2 with A1B2 and A2B1 \\
\hline
\end{tabular}

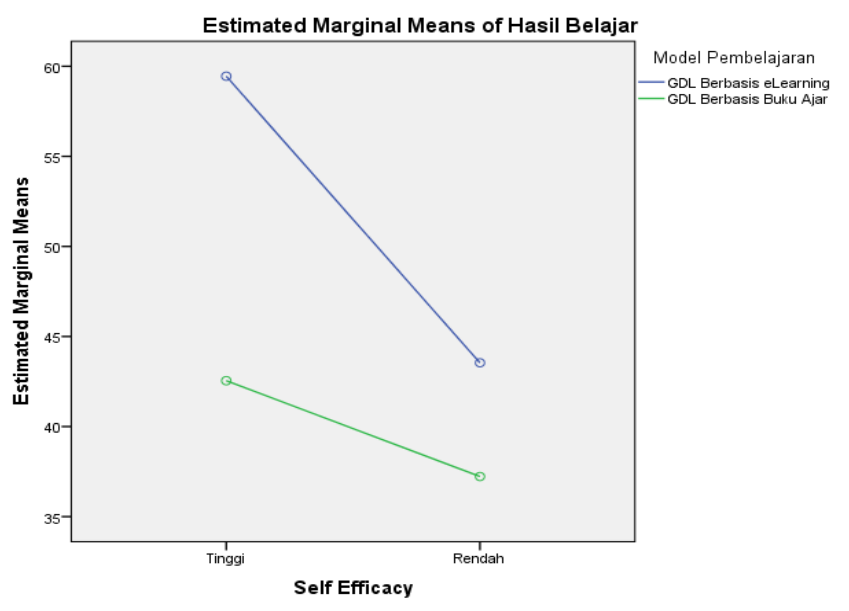

Figure 1. The interaction of learning model

Figure 3 shows that there is an interaction between Guided Discovery Learning model with Self-Efficacy on student learning outcomes in Biology class.

\subsection{The Effect of Guided Discovery Learning towards Student Learning Outcomes in Biology Class}

Based on the collected data, the result shows that there is an effect of Guided Discovery Learning model towards student learning outcomes in biology class IX of SMAN 2 Serang City. This is proven based on the value of the two-way ANOVA test results, obtained Sig. equal to 0.00 which can be obtained the Sig. $<0.05$, it was concluded that there are differences in learning outcomes in biology class between students learning with e-learning based Guided Discovery Learning model and students learning with textbooks based Guided Discovery Learning model.

Guided Discovery Learning model is a learning model that encourages students to be more active in teaching and learning activities in class so that it can encourage students to be able to understand the material described. This can be seen from the results of students' pre-test and post-test; the post-test results shows a significant difference with the students' pre-test results. This is consistent with the results of Aswardi's research (2017) which states that the Guided Discovery Learning model is a model that can improve student learning outcomes because students are more actively participating in the learning process and are able to increase students' understanding of the material provided by teachers so that student learning outcomes can improve.

The Guided Discovery Learning model is also in consistent with Science Biology, which is in line with the statement of Herlily et al. (2018) that the Guided Discovery Learning model is in accordance with science learning. This is because the learning model is able to have a high influence on students' activeness and is able to motivate student in learning more. The Guided Discovery Learning model is also able to encourage students to work together in solving problems that students must solve in each group, so students will be more actively involved in the learning process as well as in discussions or experimental activities. The learning process with Guided Discovery Learning models will help students to be directly involved in solvingproblems that will create meaningful contextual learning.

The Guided Discovery Learning model is designed as a learning model that students directly acquire their own knowledge and have the skills to participate in groups. The systematic learning process in solving problems can gradually make students understand each material learned, in line with the statement of Hayati \& Berlianti (2014) which states that the activities contained in the Guided Discovery Learning model can make student's learning activities more meaningful because students construct own knowledge so it will increase students' understanding and improve students' learning outcomes.

Learning model used in the tested class is guided discovery learning model based on e-learning and guided discovery learning model based on textbooks. Based on the results of the study, students in the tested class who use the guided discovery learning model based on e-learning have better grades than students who use the guided discovery learning model based on textbooks. Learning model using e-learning is more independently effective compared to learning with textbooks or conventionally, e-learning based 
model is able to encourage students to find learning material in an easy way from a variety of references. This is in consistent with the research of Zare et al. (2016) which states that e-learning learning model is more effective and can increase student creativity. Students will be helped to answer problems in learning by the availability of pictures and videos that help students understand concepts. Based on the value of the learning outcomes obtained, students who learn by e-learning have a higher value compared to students who study with textbooks. This proves that e-learning helps students improve their learning outcomes. This is consistent with the opinion of Suresh, Priya, \& Gayathri (2018) which states that e-learning learning helps improving student learning outcomes. The use of e-learning in student learning, is able to get a variety of sources that are not available in books, besides the ease of accessing material is also one of the things that helps in student learning. Based on the results of the discussion above, it can be concluded that the Guided Discovery Learning model based on e-learning can improve student learning outcomes.

\subsection{The Effect of Self-Efficacy towards Student Learning Outcomes in Biology Class}

Based on the data obtained, the data indicates that there is an effect of self-efficacy towards student learningoutcomes in biology class in grade XI of SMAN 2 in Serang City. This is proven based on the value of the two-way ANOVA test results, obtained Sig. equal to 0.00 which can be concluded if the Sig. $<0.05$, it is concluded that there are differences in student learning outcomes between students with high self-efficacy and students with low self-efficacy. These results can be interpreted that students with high self-efficacy will have good learning outcomes, while students with low self-efficacy get low learning outcomes as well. It can be concluded that self-efficacy has an effect on improving student learning outcomes in biology class.

Students with high self-efficacy will have high effort and perseverance in learning. Students with high self-efficacy will have high confidence in their own abilities that they are able to do each learning task well and correctly, according to the statement of Judge \& Bono (2011) which states that high self-efficacy can help someone in improving results or good performance and good work. This means that students with high selfefficacy will have confidence in themselves that they are able to carry out learning activities well by using good methods so it will help students to get high learning outcomes.

On other hand, students with low self-efficacy will also have a low level of confidence in their own abilities they have so that they feel that they have never been able to participate in learning activities properly so that it will result in the low learning outcomes they get. Students with low self-efficacy will tend to avoid completing each learning task they get, so this can affect student learning outcomes, in line with the statement of Schunk (2012) which states that students who have low self-efficacy will stay away in their efforts to complete study assignments.

High self-efficacy will also encourage and increase student motivation in learning indirectly in accordance with the statement of Colquitt, Le Pane, \& Wesson (2011) which states that a person with high self-efficacy will bring up motivation in every work they do, so this motivation will encourage a person to be persistent and diligent in completing work well and with optimal results in accordance with the statements of Firmansyah, Komalasari, \& Rusdi, (2018) which states that students with high self-efficacy will increase learning motivation, and increased motivation learning will have an impact on achieving high learning outcomes.

Based on some of those opinions above, it can be concluded that students with high self-efficacy will also have high motivation in doing every learning task they get, this motivation will encourage students to be active in completing their learning tasks well and so that students can get good results which is also in accordance with the statement of Robbins \& Judge (2013) which states that students with high motivation have the ability to maintain and increase perseverance, intensity and direction in doing the learning tasks well to achieve the goals they want.

Based on the research data obtained and the theory, it can be concluded that there is an effect of selfefficacy towards student learning outcomes in Biology class. This is evidenced that students with high selfefficacy get high learning outcomes as well.

\subsection{The Effect of Interaction between Guided Discovery Learning and Self-Efficacy towards Student} Learning Outcomes in Biology Class

Interaction is a combination of the Guided Discovery Learning model and Self-Efficacy. One step in Guided Discovery Learning is a generalization, in this step a presentation of the results of the work is done, students with different Self-Efficacy show different learning outcomes, students with low Self-Efficacy are unsure of the results of the work they are doing so that it affects the learning outcomes, this along with Zulva's statement (2019). Therefore, when teachers teach with a model, they must pay attention to aspects of Self-Efficacy. 
Based on the results of the study, the results obtained Sig. $0.014<0.05$ which means there is an effect of interaction between guided discovery learning and self-efficacy towards student learning outcomes in biology class. This is consistent with the results of the research done by Umam \& Zamtinal (2016) that there are differences in student learning outcomes using Guided Discovery Learning with student learning outcomes using conventional learning. This is because the Guided Discovery Learning model is studentcentred learning and is able to encourage students to guess, investigate, draw conclusions, and allow teachers to conduct instructions so that students are able to find their own concepts in finding their knowledge (Yoppy, 2011). In addition, the Guided Discovery Learning model is also a learning model rooted in constructivism, so students must find out for themselves and transform complex information (Trianto, 2007). Learning discovery in the Guided Discovery Learning model is an examination-based learning. Initially students will be given questions to answer a problem to be resolved and explained the results of the settlement, so that the conceptual findings are found based on the facts obtained (Risnita, 2011).

Based on the results of the study there is an effect of the interaction between self-efficacy and student learning outcomes. Students with high self-efficacy have high confidence in the actions they take will succeed. This is in accordance with the theory of Judge \& Bono (2011) which states that a person with high self-efficacy affects the performance they do. This theory is in line with the results of the study found that students with high self-efficacy are successful in learning activities which means students get high learning outcomes. The results of this study also prove that students with low self-efficacy get low learning outcomes. This is consistent with the opinion of Mulyadi, Heru, \& Wahyu (2016) that states that academic self-efficacy has a direct effect on learning. In addition, Schunk (2012) states that students with low self-efficacy will get low learning outcomes. So, based on the theories there is a possibility that students with low self-efficacy tend to stop in trying to solve every problem given by the teacher during the teaching and learning process. Based on these theories it can be concluded that there is an effect of interaction between the guided discovery learning model and self-efficacy towards student learning outcomes.

\section{References}

Anderson NW and David R.Krathwohl. (2001). A Taxonomy for Learning, Teaching, and Assesing. Addison Wesley Longman,Inc.

Aswardi. (2017). The Implementation of Guided Discovery Learning Method to Improve Student Learning Outcomes at Electromagnetic Control System and Operation Course. The International Journal of Counseling and Education, 2 (2). DOI: https://doi.org/10.23916/0020170210520

Baroody, A. J., Purpura, D. J., Eiland, M. D., \& Reid, E. E. (2014). The impact of highly and minimally guided discovery instruction on promoting the learning of reasoning strategies for basic add-1 and doubles combinations. Early Childhood Research Quarterly, 756(3), 1-13. https://doi.org/10. 1016/j.ecresq.2014.09.003

Bandura, A. (1997). Self-efficacy: The exercise of control. New York: W.H. Freeman and Company.

Budi Oetomo, Sutedjo Dharma (2002). Education Konsep Teknologi dan Aplikasi Internet Pendidikan, Yogyakarta: Percetakan And

Carin, A.A. \& Sund, R.B. (1975). Teaching Science trough Discovery, 3rd Ed. Columbus: Charles E. Merrill Publishing Company.

Chanda, Casmir. (2008). teaching and Learning of English in Secondary Schools: A Zambia Case Study in Improving Quality. London: Commonwealth Secretariat.

Chinedu, C. C., Olabiyi, O. S., \& Kamin, Y. Bin. (2015). Strategies for improving higher order thinking skills in teaching and learning of design and technology education. Journal of Technical Education and Training, 7(2), 35-43.

Retrieved from http://penerbit.uthm.edu.my/ojs/index.php/JTET/article/view/1081/795

Colquitt, Jason A., Jeffery A. LePine., Michael J. Wesson. (2009). Organizational Behavior. New York: McGraw-Hill International Companies

Dimyanti dan Mujdiono.( 2009). Belajar dan Pembelajaran. Jakarta: Rineka Cipta.

Djamarah. (2002). Psikologi Belajar. Jakarta: Rineka Cipta.

Djiwandono Sri Esti Wuryani. (2002). Psikologi Pendidikan. Grasindo JakartaDruckman, D., \& Ebner, N. (2017). Discovery Learning in Management Education: Design and Case Analysis. Journal of Management Education, 00(0), 1-28. https:// doi.org/10.1177/1052562917720710

Ersanli, C. Y. (2015). The relationship between students' academic self-efficacy and language learning motivation: A study of 8th graders. Procedia - Social and Behavioral Sciences, 199, 472-478. https://doi.org/10.1016/j.sbspro.2015.07.534

Fajri, H. N., Johar, R., \& Ikhsan, M. (2016). Peningkatan kemampuan spasial dan self-efficacy siswa melalui model discovery learning berbasis multimedia. Jurnal Tadris Matematika, 9(2), 180-196. Retrieved from https://dx.doi.org/10.20414/betajtm.v9i2.14 
Gholamian, A. (2013). Studying the Effect of Guided Discovery Learning on Reinforcing the Creative Thinking of Sixth Grade Girl Students in Qom during 2012-2013 Academic Year, 8(October), 576-584.

Gorbunovs, A., Kapenieks, A., \& Cakula, S. (2016). Self-discipline as a key indicator to improve learning outcomes in e- learning environment. Procedia - Social and Behavioral Sciences, 231(May), 256-262. https://doi.org/10.1016/j.sbspro.2016.09.100

Hamalik, Oemar. 2008. Kurikulum dan Pembelajaran. Jakarta: Sinar Grafika

Hayati, Nur., \& Berlianti, Nindha Ayu. (2016). Peningkatan Aktivitas dan Hasil Belajar Mahasiswa Univesitas Hasyim Asy'ari melalui Pembelajaran Discovery Terbimbing. Jurnal Pendidikan Biologi Indonesia, 2 (3).

Herlily, Vera., Anhar, Azwir., Ahda, Yuni., \& Sumarmin, Raadhan. (2018). Application of Learning Model Learning Guided Discovery Learning With Scientific Approach to Enhace Learning Competency Science Sevent Grade Students. International Journal of Progressive and Technologies, 6 (2).

Hietajärvi, L., Tuominen-soini, H., Hakkarainen, K., \& Salmela-aro, K. (2015). Is student motivation related to socio-digital participation? A. Procedia - Social and Behavioral Sciences, 171, 1156-1167. https://doi.org/10.1016/j.sbspro.2015.01.226

Jacob, W. J., \& Gokbel, V. (2017). International Journal of Educational Development Global higher education learning outcomes and fi nancial trends : Comparative and innovative approaches. International Journal of Educational Development, 1859(2016). https://doi.org/10.1016/j.ijedudev.2017.03.001

Judge, T. A., \& Bono, J. E. (2001). Relationship of core self-evaluations traits, self-esteem, generalized selfefficacy, locus of control, and emotional stability with job satisfaction and job performance: A metaanalysis. Journal of Applied Psychology, 86(1), 80-92. https://doi.org/10.1037/0021-9010.86.1.80

Kementerian Pendidikan dan Kebudayaan. (2017). Penyusunan Soal Higher Order Thingking Skill (HOTS). Retrieved From http://suwatno.staf.upi.edu/files/2017/11/10.-Modul-Penyusunan-Soal-HOTSTahun-2017

Lang Helmut R, David N Evan. (2006). Models, Strategies, and Methods For Effective Teaching, Pearson Education Inc.

Lenz, R Elizabeth. (2002). Self-Efficacy In Nursing Research and Measurement Perspectives. Springer Publishing Company.

Maddux James E. (2013). Self-Efficacy adaptation and adjusment: theory, Research and aplication: Theory, Reseacrch, and Aplication. Springger.

McDonald, E Mary. (2013). The Nurse Educator's Guide to Assessing Learning Outcomes 3rd Edition. England: Jones \& Bartlett Learning

Moore, J. L., Dickson-deane, C., \& Galyen, K. (2011). Internet and Higher Education e-Learning, online learning, and distance learning environments : Are they the same? The Internet and Higher Education, 14(2), 129-135. https://doi.org/10.1016/j.iheduc.2010.10.001

Mulyadi, S., Basuki, A. M. H., \& Rahardjo, W. (2016). Student's Tutorial System Perception, Academic SelfEfficacy, and Creativity Effects on Self-Regulated Learning. Procedia - Social and Behavioral Sciences, 217, 598-602. https://doi.org/10.1016/j.sbspro.2016.02.059

Murtonen, M., Gruber, H., \& Lehtinen, E. (2017). The return of behaviourist epistemology : A review of learning outcomes studies. Educational Research Review, 22, 114-128. https://doi.org/10.1016/i.edurev.2017.08.001

Peraturan Menteri Pendidikan dan Kebudayaan Republik Indonesia Nomor 59 Tahun 2014. (2014). Retrieved From http://simpuh.kemenag.go.id/regulasi/permendikbud_59_14.pdf

Risnanosanti. 2010. “Kemampuan Berpikir Kreatif Matematis dan Self-Efficacy terhadap Matematika Siswa Sekolah Menengah Atas (SMA) dalam Pembelajaran Inkuiri". Disertasi Doktor pada SPS. UPI: Tidak diterbitkan.

Robbins, Stephen P \& Judge, Timothy A. 2013. Organizational Behavior Edition 15. New Jersey: Pearson Education

Schunk, D. H. (2012). Learning theories. Printice Hall Inc., New Jersey (Vol. 53). https://doi.org/10.1017/CBO9781107415324.004

Sharifah, R., \& Faaizah, S. (2015). The Development of Online Project Based Collaborative Learning using ADDIE Model. Procedia - Social and Behavioral Sciences, 195, 1803-1812. https://doi.org/10.1016/j.sbspro.2015.06.392

Slameto. 2010. Belajar dan faktor-faktor yang Mempengaruhinya. Jakarta: PT. Rineka Cipta

Suresh, Manya., Priya, V. Vishu., Gayathri, R. (2018). Effect of E-learning on Academic Performance of Undergraduate Students. Drug Invention Today, 10 (9).

Undang-Undang Republik Indonesia No 20 Tahun 2003 Tentang Sistem Pendidikan Nasional. (2003). Retrieved From content/uploads/2016/08/UU_no_20_th_2003.pdf

Unoo Hamza B, Masri Kudrat Umar, Keysar Panjaitan. 2014.Variabel Penelitian dalam Pendidikan dan Pembelajaran. PT.Ina Publikatama 
Widyastuti, E. S. (2014). Penerapan model pembelajaran discovery learning pada materi konsep ilmu ekonomi. Prosiding Seminar Nasional, 33-40. Retrieved from https://eprints.uny.ac.id/21658/1/04 Ellyza Sri Widyastuti.pdf

Whittaker, James O. (1976). Introduction to Psychology. England: Harcourt Brace College Publishers.

Woodman, J., Ballard, K., Hewitt, C., \& Macpherson, H. (2018). European Journal of Integrative Medicine Self-e ffi cacy and self-care-related outcomes following Alexander Technique lessons for people with chronic neck pain in the ATLAS randomised, controlled trial it. European Journal of Integrative Medicine, 17(August 2017), 64-71. https://doi.org/10.1016/j.eujim.2017.11.006

$\mathrm{Wu}, \mathrm{J}$. (2017). Computers \& Education The indirect relationship of media multitasking self-ef fi cacy on learning performance within the personal learning environment: Implications from the mechanism of perceived attention problems and self-regulation strategies. Computers \& Education, 106, 56-72. https://doi.org/10.1016/j.compedu.2016.10.010

Zaini, Muhammad. 2015. Hasil Belajar Dan Keterampilan Berpikir Tingkat Tinggi Siswa SMA Pada Pembelajaran Biologi Menggunakan Model pembelajaran Berdasarkan Masalah. Jurnal Pendidikan Biologi. Vol 20 (207). Retrieved From http://eprints.ulm.ac.id/845/

Zare, M., Sarikhani, R., \& Mansouri, V. (2016). The Impact of E-learning on University Students Academic Achievement and Creativity. Journal of Technical Education and Training. 8 (1).

Zetou, E., Vernadakis, N., Derri, V., \& Bebetsos, E. (2014). The effect of game for understanding on backhand tennis skill learning and self-efficacy improvement in elementary students. Procedia - Social and Behavioral Sciences, 152, 765-771. https://doi.org/10.1016/j.sbspro.2014.09.318

Zikri, Neni Iska. (2008) Psikologi Pengantar Pemahaman Diri dan Lingkungan. Jakarta: Kizi Brother.

Zimmerman, B. J. (2000). Self-Efficacy: An Essential Motive to Learn. Contemporary Educational Psychology, 25, 82-91. https://doi.org/10.1006/ceps.1999.1016

Zulkosky, K. (2009). Self-Efficacy: A Concept Analysis. Journal Compilation, 44 (2),93-102. https://doi.org/https://onlinelibrary.wiley.com/doi/abs/10.1111/j.1744-6198.2009.00132.

Zulfa, Aulia, (2019). Kemampuan Komunikasi Matematis Ditinjau dari Self-Efficacy melalui Guided Discovery Learning Berbantuan Immediate Feedback, Tesis. Universitas Negeri Semarang. 